Збірник наукових пращь Державного науково-дослідного інституту випробувань і сертифікачї̈ озброєння та військової техніки. 2019. Вип. № 2

Корнієнко І.В., Корнієнко С.П. Чернігівський національний технологічний університет Походенко О.М., Казначей С.М., Руденко О.В. Державний науково-дослідний інститут випробувань і сертифікачї озброєння та військової техніки

\title{
ГРАФІЧНЕ ПРЕДСТАВЛЕННЯ МОДЕЛІ ФУНКЦІОНУВАННЯ ВИПРОБУВАЛЬНОЇ ОРГАНІЗАЦІї
}

У статі розглянута проблема управління ефективністю функціонування випробувальної організації. Запропоновано графічну модель системи масового обслуговування (СМО) випробувальної організації у різних варіаціях обслуговування потоку заявок. Акцентовано увагу на відмінностях запропонованої моделі від традииійних СМО. Зроблені припущення щчодо закономірностей вхідного потоку та параметрів обслуговування СМО, а також окреслені завдання на подальші дослідження тематики.

Ключові слова: випробувальна організація, система масового обслуговування, ефективність функиіонування.

Актуальність. Функціонування будь-якої випробувальної організації пов'язане перш за все 3 систематичним, чітким та безвідмовним виконанням випробувань 3 визначення якості, властивостей та характеристик конкретної продукції. Успіх цього завдання залежить від багатьох факторів, основними серед яких $\epsilon$ достатність у забезпеченні фахівцями, відповідного випробувального обладнання та устаткування. При забезпеченні цієї умови та умови стаціонарності потоку надходжень зразків для випробувань, ефективність управління діяльністю випробувальної організації полягає у ретельному плануванні випробувань та раціональному розподіленні ресурсів (сил та засобів для випробування).

Проте, іноді можуть траплятися випадки, які можуть чинити негативний вплив на процес проведення випробувань. Наприклад, коливання інтенсивності вхідного потоку зразків для випробувань, що на практиці пояснюється зростом або занепадом науковотехнічного сектору, пожвавленням або спадом економіки, нагальною потребою держави у певних галузевих видах продукції, технологічним проривом у конкретному секторі економіки тощо, призведуть до простою або перевантаження випробувальної організації. Результатом цього $є$ перевитрати на утримання організації або затримка у створенні продукції i, як наслідок, певна втрата іiі конкурентоспроможності. Окрім вхідного потоку зразків для випробувань, чималий вплив на успішність діяльності випробувальної організації чинить сам процес випробувань, якій може прискорюватись або гальмуватись незалежно від внутрішніх чинників. I, нарешті, різнорідність і різноплановість зразків продукції, які надходять на випробування, потребуватимуть застосування оптимізаційних методів планування для зменшення втрат з простою випробувального процесу.

3 цього виникає задача управління ефективністю функціонування випробувальної організації. Формальна постановка такого завдання, на наш погляд, може мати наступну форму.

Постановка завдання. $€$ випробувальна організація, що виконує завдання 3 проведення випробувань і сертифікації широкого спектру технічних та інших засобів, які за їх функціональним призначенням можна класифікувати на декілька окремих груп (класів). Випробування можуть проводитись на різних стадіях життєвого циклу досліджуваних зразків або систем. Заявки на проведення випробувань, як правило, мають плановий характер, проте, не виключена наявність стохастичного процесу надходження заявок, що пов'язано з факторами появи нових зразків вищого пріоритету важливості, які терміново потребують випробувань; доробок зразків, які раніше були зняті 3 випробувань; 
дострокового виготовлення та готовності зразків (для уникнення простою виробничого процесу на етапі випробовувань та прискорення випуску готової продукції).

Фактичні випробування здійснюються фахівцями 3 використанням обладнання та устаткування, які спеціалізуються та призначені для випробування певних груп (класів) технічних та інших засобів або їх окремих елементів.

С потреба в такому управлінні діяльністю випробувальної організації, щоб забезпечити обслуговування заявок на випробування 3 якістю не нижче заданої та мінімальним часом очікування на випробування (простоєм заявок).

Виклад основного матеріалу. За такої постановки задачі ефективного управління процесом організації випробувальної діяльності необхідно формалізувати всі процеси, що відбуваються 3 моменту надходження заявки (групи заявок) на випробування до моменту виконання випробувань (підписання актів, звітів з випробувань тощо).

Серед класів оптимізаційних задач, які розглядають масовий попит на обслуговування, широко відомий і добре розвинений апарат аналітичних моделей систем масового обслуговування (CMO). При застосуванні такого математичного апарату, діяльність випробувальної організації можна представити через роботу багатоканальної СМО з очікуванням та відмовами, загальний випадок моделі якої можна представити рисунком 1 .

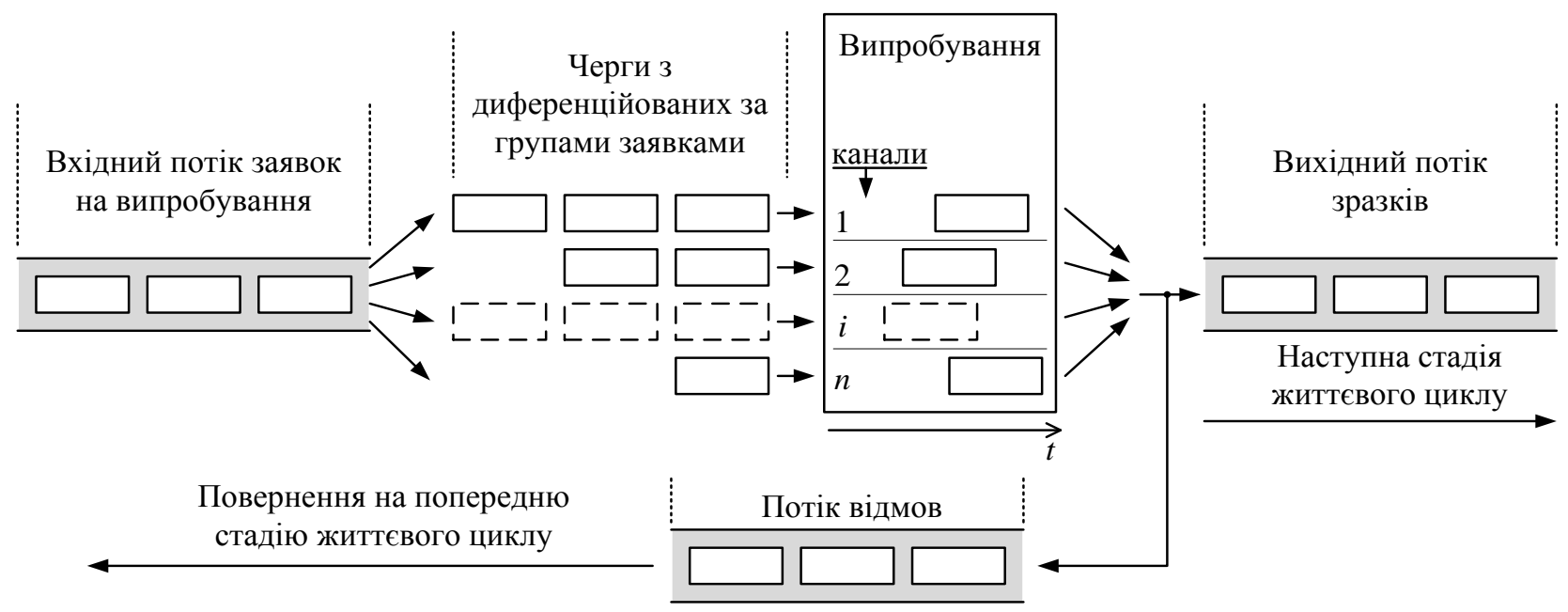

Рис. 1. Модель багатоканальної СМО з очікуванням та відмовами

Представлена модель СМО має певні особливості, які відрізняють ії аналітичний опис від традиційних багатоканальних СМО з відмовами, які наведені, наприклад, у [1]. Поперше, вхідний потік заявок представляє собою потік неоднорідних технічних засобів, що утворюють різні класи (групи). Ці групи (класи) зразків обслуговуються визначеними та “закріпленими” за такими групами каналами (на практиці, наприклад, техніка зв'язку досліджується фахівцями зв'язківцями).

По-друге, зазвичай, відмовою (втратою) заявки приймається випадок, коли заявка на обслуговування втрачається внаслідок зайнятості всіх каналів. Таке представлення відмови справедливо для СМО без очікування заявок у черзі. Для СМО з очікуванням, відмовою заявці, зазвичай, вважається перевищення деякого граничного часу очікування заявки у черзі або обмеженою довжиною черги. В обох випадках втрачена заявка не поступає на обслуговуючий пристрій (рис. 2). 


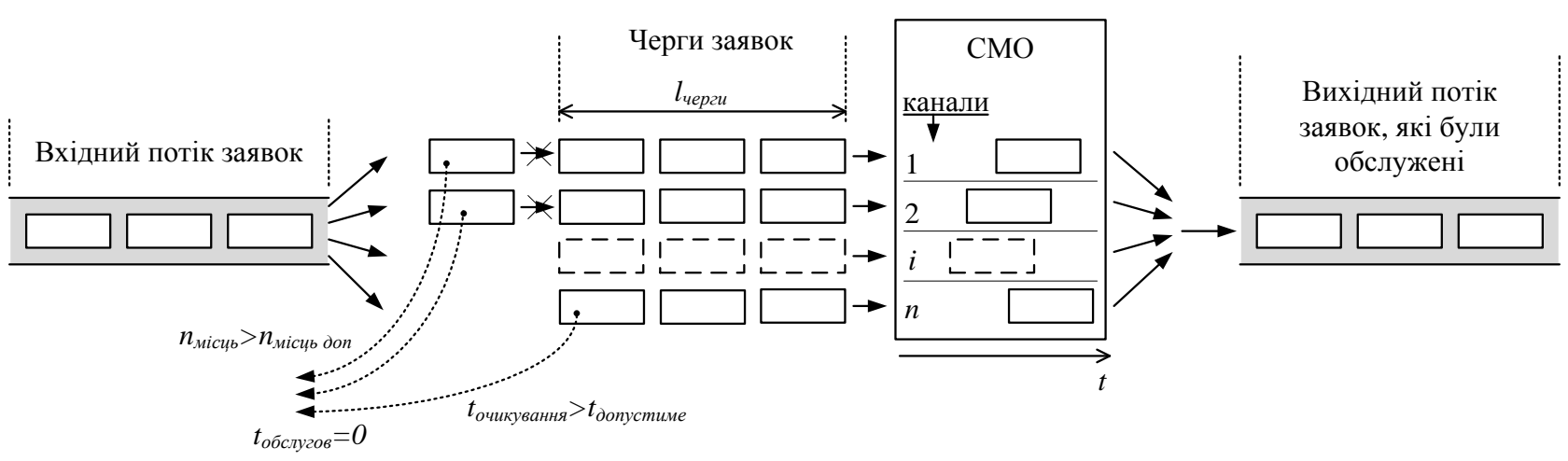

Рис. 2. Традиційне представлення відмов в обслуговуванні (втрат) заявок

Передбачається, що втрачені заявки (або їх частина) у подальшому можуть повторно надійти для обслуговування на вхід СМО. Вочевидь, що таке повернення до обслуговування в певній мірі збільшуватимуть загальний потік заявок на обслуговування. Проте, важливим при моделюванні процесу відмови заявці в обслуговуванні, для традиційних моделей, є те, що відмова відбувається на вході обслуговуючого пристрою, тобто обслуговуючий пристрій СМО не витрачає час на втрачену заявку.

При розгляді СМО випробувань (рис. 1) втратою вважається заявка, обслуговування

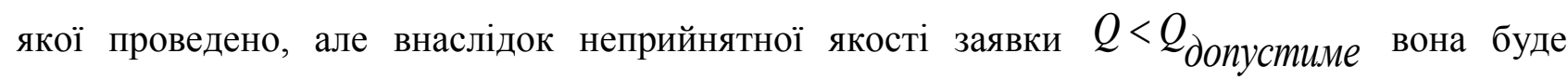
повернута на доопрацювання. У подальшому слід передбачати, що втрачені заявки, як і в розглядуваних раніше випадках, будуть повторно надіслані на вхід СМО. Необхідно зазначити, що суттєвою відмінністю від випадку, який зображений на рисунку $2 \epsilon$ те, що втрата заявки відбувається після іiї обслуговування, тобто обслуговуючий пристрій СМО витрачає час на обслуговування заявки, яка в подальшому вважатиметься втраченою (рис. 3).

Іншою характерною рисою СМО є те, що на вхід СМО можуть бути подані заявки на обслуговування складних, комплексних зразків техніки, що потребуватимуть залучення декількох фахівців, обладнання або устаткування 3 різних тематичних груп (класів). В інтерпретації обслуговуючого пристрою СМО такі заявки можуть займати декілька обслуговуючих каналів (рис. 4).

Формування аналітичного опису обслуговування такої СМО, безперечно, потребуватиме введення синхронізації в обслуговуванні “суміжними” каналами (введемо цей термін для позначення каналів, що одночасно обслуговують одну й ту ж заявку). Спрощення аналітичного опису можливо шляхом розділення складної заявки на “підзаявки”, які одночасно (симетрично) обслуговуватимуться у суміжних каналах (рис. 5).

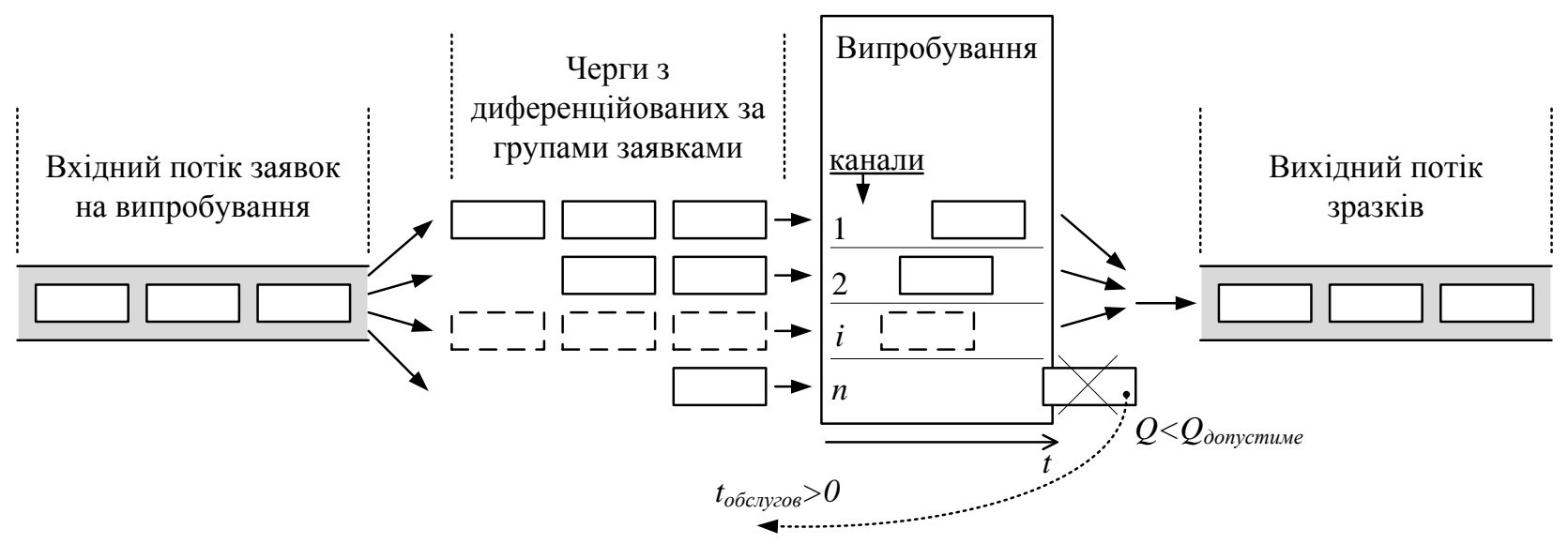

Рис. 3. Відмови в обслуговуванні (втрати) заявок у СМО системи випробувань 


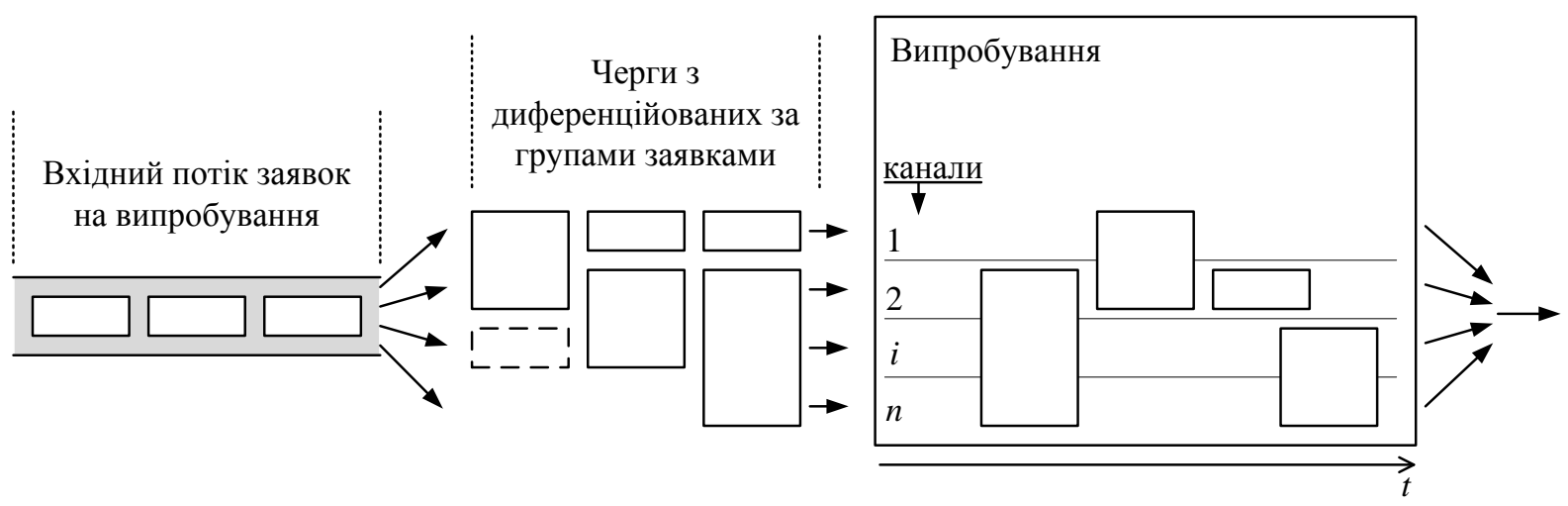

Рис. 4. Обслуговування заявок декількома обслуговуючими каналами

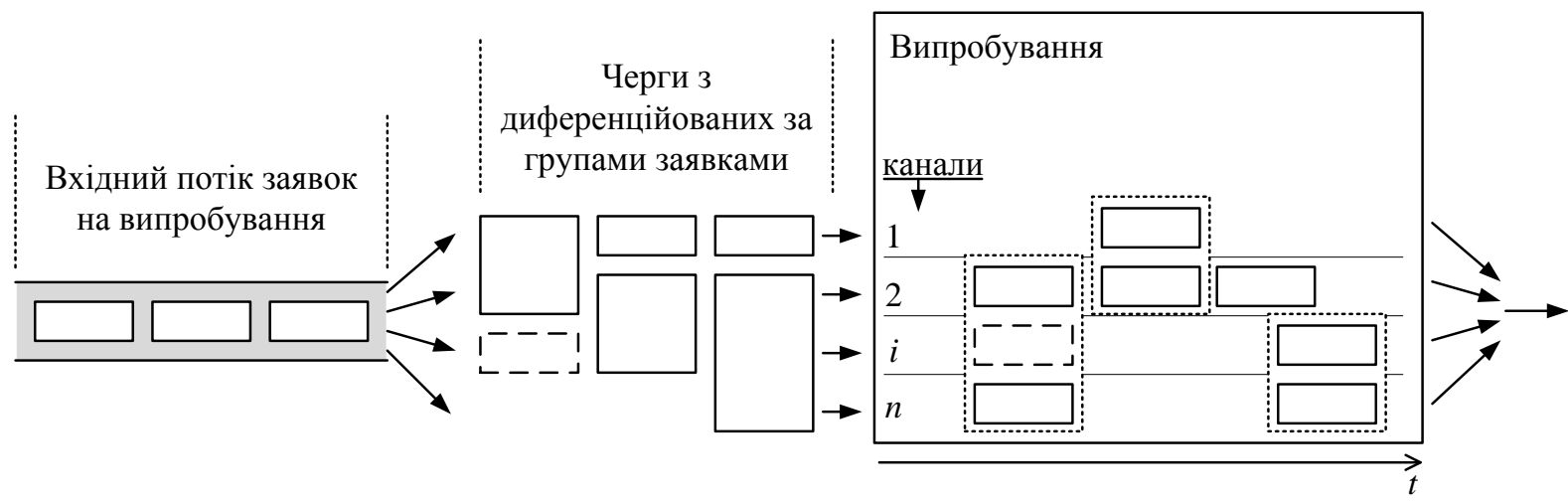

Рис. 5. “Синхронізація” обслуговування заявок декількома обслуговуючими каналами

Також, природно припустити, що особливо складні зразки технічних засобів потребуватимуть поетапних випробувань, тобто з послідовним заняттям суміжних каналів у різних варіаціях (рис. 6). Таке поетапне випробовування на практиці можна представити послідовним залученням різних фахівців, що випробовують кожен свій конкретний бік (властивість, характеристику) досліджуваного зразку, коли їх одночасне залучення до випробувань неможливе або недоцільне.

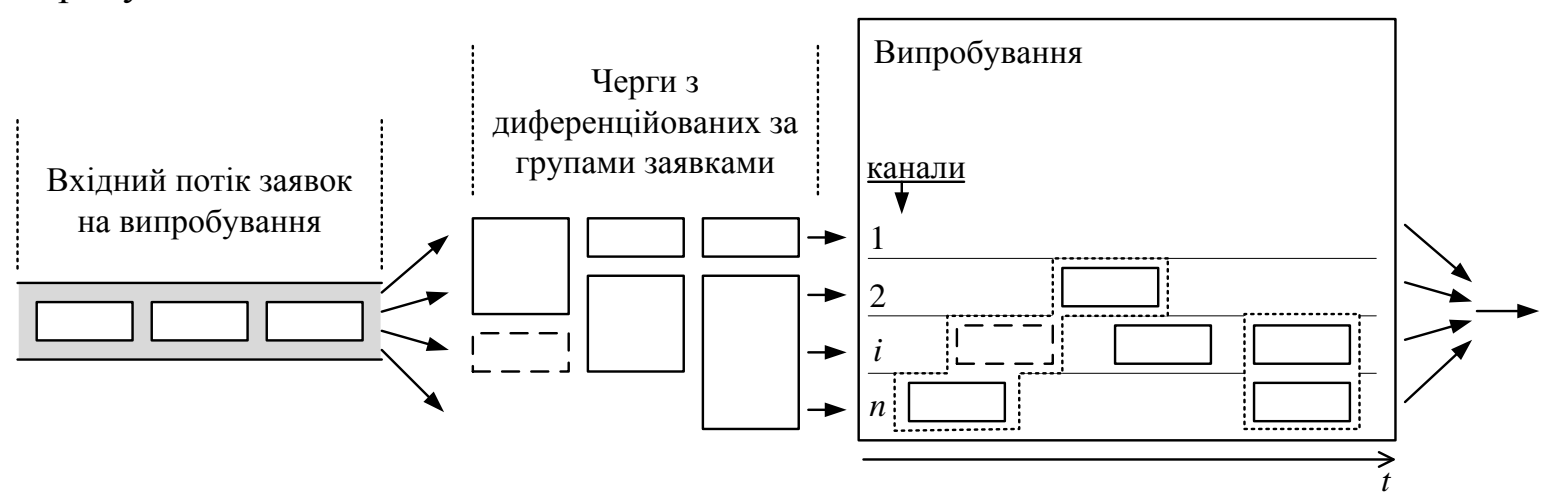

Рис.

6. Поетапне обслуговування “складноі”” заявки декількома обслуговуючими каналами

Іншим фактором, що впливатиме на опис процесів обслуговування є пріоритетність та час обслуговування заявок. Під пріоритетністю, зазвичай, вважається важливість заявки, що поступає на обслуговування. У випадку пріоритетності заявки над іншими вона обслуговується у першу чергу (рис. 7). 


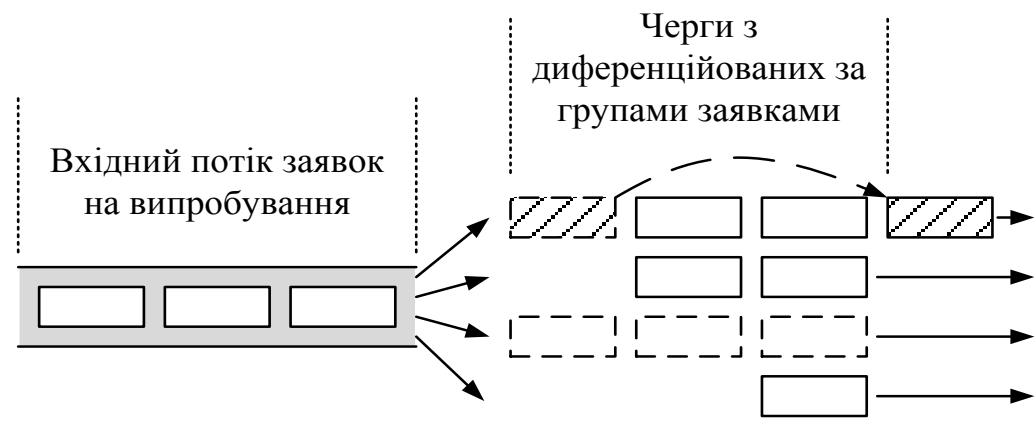

Рис. 7. Пріоритетне обслуговування заявки

У традиційних СМО з відмовами та обмеженим часом i/або обмеженою чергою заявок поява пріоритетної заявки (групи заявок з вищим пріоритетом) ставить під загрозу обслуговування заявок з нижчим пріоритетом. Проте, у нашому випадку, очевидно, що пріоритетні заявки не чинитимуть суттєвий вплив на функціонування системи в цілому, так як час очікування заявок у черзі або довжина черги очікування апріорі не обмежується.

Різні витрати часу на обслуговування заявки можуть бути пов'язані 3 різною трудомісткістю або складністю випробувальних операцій (рис. 8). 3 рисунку 8 видно, що час обслуговування заявки у першому каналі набагато більший, ніж в інших каналах. Наприклад, 3 наведеного на рисунку 8 прикладу, для часу обслуговування заявок по каналах $t_{1}>t_{n}>t_{2}$.

Для подальшого аналітичного моделювання СМО та визначення ii оптимальної структури та параметрів, які забезпечать ефективне функціонування випробувальної організації, необхідно визначити характеристики вхідного потоку та параметри обслуговуючого пристрою. Надалі окреслимо основні підходи, щодо визначення параметрів вхідного потоку та характеристик обслуговуючих каналів.

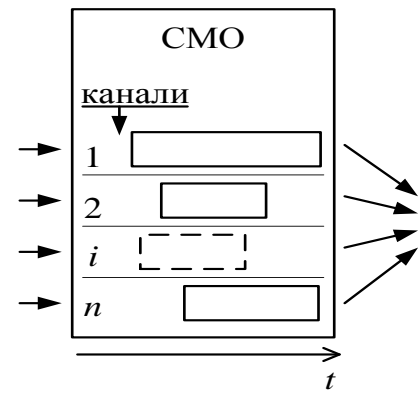

Рис. 8. Обслуговування заявок з різною вагою.

Прийнято вважати, що оптимальним для простоти аналітичного моделювання СМО є рекурентний потік [2], тобто стаціонарний, ординарний потік з обмеженою післядією. Якщо прийняти, що сортування вхідних заявок за каналами обслуговування здійснюється до моменту потрапляння заявок в обслуговуючий пристрій СМО (тобто виконуються умови ординарності потоку), то для нашого випадку можна вважати, що вхідний потік заявок $\epsilon$ рекурентним потоком. Таке припущення суттєво спростить, у подальшому, процес аналітичного моделювання процесів СМО.

Також, на наш погляд, природно припустити гіпотезу, що часовий інтервал між надходженнями $\Delta t_{i}^{n}$ (як часовий інтервал між підготовкою $i$-го зразка $n$-им розробником до випробувань) матиме вигляд експоненціальне розподіленої випадкової величини, для якої функція та щільність розподілу мають вигляд відповідно [3]:

$$
\begin{gathered}
F(t)=1-e^{-\lambda t} ; \\
f(t)=\left\{\begin{array}{l}
0, \text { nри }-\infty<t<0 ; \\
\lambda e^{-\lambda t}, \text { при } 0 \leq t<+\infty,
\end{array}\right.
\end{gathered}
$$


де $\lambda$ - інтенсивність потоку (в нашому випадку $\lambda=\lambda_{i}^{n}$ ).

Для такого потоку імовірність надходження $k$ заявок на випробування за інтервал $\Delta T$ визначається законом Пуассона:

$$
P_{k}(\Delta T)=\frac{(\lambda \Delta T)^{k}}{k !} e^{-\lambda \Delta T} ; k=0,1, \ldots
$$

Властивостями пуассонівського потоку, як одного 3 рекурентних потоків, $\epsilon$ стаціонарність, ординарність та відсутність післядії. Тоді, за властивістю рекурентних потоків, інтенсивність сумарного потоку заявок на випробування від $N$ виробників, що потрапляють на вхід СМО, є також пуасонівським потоком 3 інтенсивністю $\Lambda=\sum_{i=1}^{N} \lambda_{i}$. Потрібно відмітити, що для практичного застосування, висунуте припущення щодо пуасонівського потоку підлягає подальшій статистичній перевірці.

Як відомо, основною характеристикою каналу обслуговування є час, що знадобиться

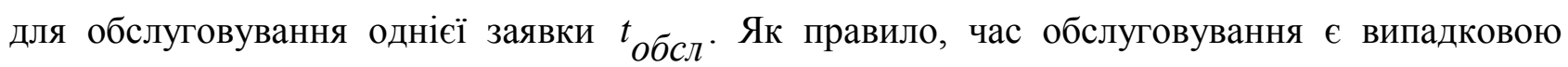
величиною, яку можна описати відповідним законом розподілу ймовірностей, за умови, наявності відповідних статистичних даних. Проблемою, що може завадити визначенню закону розподілу ймовірності випадкової величини, $є$ мала вибірка за суттєвою різнорідністю зразків, які надходять на випробування і відносяться до різних класів, типів та проходять різні стадії життєвого циклу. У цьому випадку, можна використовувати математичне очікування часу обслуговування заявки, обчислене як середньозважене по частоті проявів випадкової величини з генеральної вибірки.

За потреби можна прогнозувати час обслуговування конкретного зразку. Очевидно, що величина $t_{\text {обсл }}$ визначатиметься певним переліком зовнішніх та внутрішніх чинників, що впливатимуть на процес випробувань конкретного зразка. До таких чинників можна віднести, наприклад, стадію життєвого циклу зразка, погодні умови, підготовленість фахівця 3 випробувань, наявність випробувального обладнання у достатній кількості і специфікаціях, прилаштованість випробувального обладнання до випробувань (ефективність застосування випробувального обладнання), складність зразка, трудомісткість випробувань тощо. Встановлення переліку та величини впливу таких чинників, на час випробувань однотипних зразків, дозволить одержувати наближені оцінки часу обслуговування вхідних заявок у залежності від типу та параметрів зразків, а відповідно, і всі інші статистичні та ймовірнісні характеристики обслуговуючого пристрою СМО.

Одержати можливі значення показників впливу (як додатних, так і від’ємних) внутрішніх та зовнішніх чинників на основний показник обслуговуючого пристрою $t_{\text {oбсл }}$ можна через встановлення кореляційної залежності на основі масиву статистичних даних, як це показано, наприклад, у працях $[4,5]$.

Зрозуміло, що аналітичне представлення всіх наведених процесів виводить дану тематику за межі обсягу наукової статті, тому автори залишають за собою можливість подальшого розгляду та висвітлення проблематики у наступних працях.

Висновок. Запропонована графічна модель СМО випробувальної організації та варіації обслуговування заявок впритул підводить до можливості аналітичного моделювання функціонування випробувальної організації. Висунуте припущення щодо закону розподілу вхідного потоку заявок за його статистичного підтвердження суттєво спростить моделювання процесів у СМО. У той же час, статистичне прогнозування часу випробувань конкретних зразків у системі надасть можливість прогнозувати та оптимізувати план виконання випробувань. 
Отже, подальше коректне аналітичне моделювання процесів функціонування випробувальної організації дозволить створити систему ефективної організації, планування та управління випробуваннями.

\section{СПИСОК ЛІТЕРАТУРИ}

1. Клейнрок Л. Теория массового обслуживания. Перевод с англ. / Пер. И.И. Грушко; ред. В. И. Нейман. - М.: Машиностроение, 1979. - 432c.

2. Казачинский В.3. Математические методы решения военно-специальных задач. / В.3. Казачинский, Г.Е. Левитский. - К.: ВА ВПВО, 1980. - 292 с.

3. Вентцель Е. С. Теория вероятностей. / Е. С. Вентцель. - М.: Наука, 1969. - 4-е изд. $-576 \mathrm{c}$.

4. Корнієнко І.В. Підхід до розв'язування задачі розподілу ресурсу в неточно визначених умовах / І. В. Корнієнко, В. М. Лось, С. П. Корнієнко // Вісник Чернігівського національного педагогічного університету. - Чернігів: ЧДПУ, 2011. - № 83. - С. 36-39.

5. Корнієнко I.В. Спосіб кореляційного визначення ступеню впливу об'єктивних чинників на кількість відібраних кандидатів на військову службу за контрактом. / І.В. Корнієнко, В.П. Хома, С.П. Корнієнко // Труди університету. - К.: НУОУ, 2012. - № 2 (108). - C. 158-166.

\section{Корніснко Ігор Валентинович}

кандидат технічних наук, доцент, завідувач кафедри геодезії, картографії та землеустрою, Чернігівський національний технологічний університет, Чернігів, Україна https://orcid.org/0000-0001-9105-0780 +38066-733-07-22

\section{Корніснко Світлана Петрівна}

кандидат технічних наук, доцент, доцент кафедри промислового та цивільного будівництва, Чернігівський національний технологічний університет, Чернігів, Україна http://orcid.org/0000-0002-9162-1229 +38066-733-07-20

\section{Походенко Олександр Миколайович}

начальник $\quad$ науково-дослідного відділу випробувань i сертифікації озброєння та військової техніки, Чернігів, Україна https://orcid.org/0000-0001-6727-6835 +38063-226-75-87

\section{Казначей Станіслав Миколайович}

старший науковий співробітник науковоінформаційного відділу Державного науководослідного інституту випробувань i сертифікації озброєння та військової техніки, Чернігів, Україна https://orcid.org/0000-0003-2055-5524 +38063-667-70-67

\section{Ihor Korniyenko}

Candidate of Technical Sciences, Associate Professor, Head of Department of geodesy, cartography and land planning,Chernihiv National University of Technology, Chernihiv, Ukraine

https://orcid.org/0000-0001-9105-0780 +38066-733-07-22

\section{Svitlana Korniyenko}

Candidate of Technical Sciences, Associate Professor, Associate Professor of the Department of Industrial and Civil Engineering, Chernihiv National University of Technology, Chernihiv, Ukraine http://orcid.org/0000-0002-9162-1229 +38066-733-07-20

\section{Alexandr Pokhodenko}

Chief of Section of State Scientific Research Institute of Armament and Military Equipment Testing and Certification, Chernihiv, Ukraine https://orcid.org/0000-0001-6727-6835 +38063-226-75-87

\section{Stanislav Kaznachey}

Senior Researcher of State Scientific Research Institute of Armament and Military Equipment Testing and Certification, Chernihiv, Ukraine https://orcid.org/0000-0003-2055-5524 $+38063-667-70-67$ 
Збірник наукових прачь Державного науково-дослідного інституту випробувань і сертифікачії озброєння та військової техніки. 2019. Вип. № 2

Руденко Олег Володимирович

начальник науково-дослідної Державного науково-дослідного військової техніки, Чернігів, Україна https://orcid.org/0000-0002-8699-1057 $+38093-839-88-97$

\section{Oleh Rudenko}

лабораторії

Chief of Laboratory of State Scientific Research Institute of Armament and Military Equipment Testing and Certification, Chernihiv, Ukraine https://orcid.org/0000-0002-8699-1057 $+38093-839-88-97$

\section{GRAPHICAL REPRESENTATION MODEL OF TESTING ORGANIZATION FUNCTIONING I. Korniyenko, S. Korniyenko, A. Pokhodenko, S. Kaznachey, O. Rudenko}

The article deals with the problem of managing the effectiveness of the testing organization, which consists in careful planning of tests, rational distribution of workforce and means for testing and timely testing with obtaining accurate and reliable assessments of the suitability of weapons and military equipment to use. It is noted that the testing takes place mainly under conditions of non-stationary and stochastic external and internal processes, which significantly complicates, and sometimes makes impossible, the process of planning the test activity, and, accordingly, reduces the efficiency of testing organization functioning.

Finding effective plans for the functioning of the testing organization under uncertainty is possible through adequate system modeling and consideration of all processes that accompany the test activity, for which the use of the analytical apparatus of queuing systems is proposed. For a general consideration of the processes, an initial graphical model of the test organization's queuing system in various variations of service flow of weapons and military equipment samples to be tested is proposed. Attention is focused on the main differences between the proposed model and traditional models of queuing systems.

Proposed graphical model of testing organization queuing system and options for processing the requests closely leads to analytical modeling of testing organization functioning.

If the assumptions on the regularities of the request input stream are statistically proven, the modeling of processes in queuing system will be much easier.

It is suggested to use the correlation method to determine the dependence of the service time of specific pieces of equipment on the internal and external factors influencing the test process.

The tasks for further research of the topic, based on the decomposition of processes in queuing system tests and their correct analytical description, are outlined. The realization of such a system will allow the development and implementation of an automated test quality management system.

Keywords: test organization, queuing system, performance, operating efficiency. 